\title{
Evaluasi Manfaat Penerapan Telemedicine di Negara Kepulauan: Systematic Literature Review
}

\author{
Herwando $^{1}$, Taufiq Hamzah Sitompul ${ }^{2}$ \\ ${ }_{1}^{1}$ Program Studi Manajemen Informasi Kesehatan, Fakultas Ilmu-Ilmu Kesehatan, Universitas Esa Unggul, Jakarta, Indonesia \\ 2 Health Information Systems Program of Indonesia, Indonesia \\ 1Jl. Arjuna Utara No. 9, Kebon Jeruk, Jakarta Barat, DKI Jakarta 11510 \\ Korepondensi E-mail: wandomik@gmail.com
}

Submitted: 30 Juni 2021, Revised: 9 Desember 2021, Accepted: 16 Desember 2021

\begin{abstract}
Telemedicine is the use of medical information exchanged from one site to another through electronic communication to improve the clinical health status of patients. Telemedicine can be one of the solution options to overcome the limitations of health workers. This study aims to describe the benefits of implementing Telemedicine in archipelagic countries. This type of research is a Systematic Literature Review with literature sourced from Elsevier, Garuda, IEEE Xplore, NCBI, PubMed, ProQuest, ResearchGate, Science Direct, and Springer. Literature selection using PRISMA, obtained 257 scientific articles consisting of duplicate data 15, did not enter the topic 73, did not meet the inclusion and exclusion criteria 154, did not meet the minimum standard of SRQR 4 and only 10 were used. The results of the analysis obtained are 5 of the 19 archipelagic countries that are related, namely Cape Verde, the Philippines, Indonesia, Papua New Guinea, and Sao Tome \& Principe. Furthermore, improving access to care in the form of eliminating trips that are burdensome for patients, making it easier for patients to access health services through patient devices. The nearest Telemedicine satellite device. Then the timeliness in treatment is to facilitate the diagnosis of patients and patient health care. Then the increase in patient satisfaction and involvement of patient satisfaction and patient involvement. Meanwhile, the increase in demand and costeffectiveness is obtained in the form of efficient services, increasing patient expectations. The benefits of implementing Telemedicine are mostly in Cape Verde and the least in Papua New Guinea.
\end{abstract}

Keywords: telemedicine, telemedicine application, archipelago country

\begin{abstract}
Abstrak
Telemedicine sebagai penggunaan informasi medis yang dipertukarkan dari satu situs ke situs lain melalui komunikasi elektronik untuk meningkatkan status kesehatan klinis pasien. Telemedicine bisa menjadi salah satu opsi solusi mengatasi keterbatasan tenaga kesehatan. Penelitian ini bertujuan mendeskripsikan manfaat penerapan Telemedicine di negara kepulauan. Jenis penelitian Sytematic Literature Review dengan literatur bersumber dari Elsevier, Garuda, IEEE Xplore, NCBI, PubMed, ProQuest, ResearchGate, Science Direct, dan Springer. Seleksi literatur menggunakan PRISMA, diperoleh 257 artikel ilmiah terdiri dari duplikasi data 15, tidak masuk topik 73, tidak masuk kriteria inklusi dan eksklusi 154, tidak masuk standar minimal SRQR 4 dan hanya 10 yang digunakan. Hasil analisis yang diperoleh ada 5 dari 19 negara kepulauan yang terkait yakni Cape Verde, Filipina, Indonesia, Papua New Guinea, dan Sao Tome \& Principe. Selanjutnya pada peningkatan akses perawatan berupa menghilangkan perjalanan yang memberatkan pasien, memudahkan pasien mengakses layanan kesehatan melalui perangkat pasien/perangkat satelit Telemedicine terdekat. Lalu ketepatan waktu dalam perawatan yaitu memudahkan penegakan diagnosis pasien dan perawatan kesehatan pasien. Kemudian peningkatan kepuasan dan keterlibatan pasien adanya kepuasan pasien dan keterlibatan pasien. Sedangkan pada peningkatan permintaan dan hemat biaya diperoleh berupa layanan yang efisien, meningkatnya ekspektasi pasien. Adapun manfaat penerapan Telemedicine paling banyak di negara Cape Verde dan paling sedikit di Papua New Guinea.
\end{abstract}

Kata Kunci: telemedicine, penerapan telemedicine, negara kepulauan

\section{Pendahuluan}

Teknologi informasi dan komunikasi telah memasuki paradigma baru dan mempengaruhi semua aspek kehidupan, termasuk di bidang kesehatan. Teknologi informasi dan komunikasi memiliki peran dalam mengatasi sebuah permasalahan salah satunya untuk mengeliminasi batasan jarak masyarakat untuk mendapatkan layanan kesehatan (1). Adapun Telemedicine ialah salah satu dari kemajuan teknologi informasi dan komunikasi di bidang kesehatan. Penerapan Telemedicine sudah diterapkan oleh negara- 
negara kepulauan di dunia contohnya negara Cape Verde (Cabo Verde), Filipina, Jamaika dan Sao Tome Principe (2)(3)(4)(5)(6). Selain itu, penerapan Telemedicine memiliki manfaat meningkatkan akses perawatan, ketepatan waktu, meningkatkan kepuasan pasien, meningkatkan keterlibatan pasien, meningkatkan permintaan perawatan, dan hemat biaya (7).

Negara Kepulauan adalah negara yang seluruhnya terdiri atas satu atau lebih kepulauan dan dapat mencakup pulau-pulau lain. Kepulauan yang dimaksud adalah suatu gugusan pulau, meliputi bagian pulau dan perairan di antara pulau-pulau tersebut, dan lain-lain terbentuk alamiah yang hubungannya satu sama lain demikian erat sehingga pulau-pulau, perairan, dan wujud alamiah lainnya itu menjadi satu kesatuan geografi, ekonomi, pertahanan, dan keamanan serta politik yang hakiki atau yang secara historis (8). Di beberapa negara kepulauan memiliki masalah di bidang kesehatan salah satunya di negara Indonesia (9). Pada tahun 2016 negara Indonesia dihadapi salah satu masalah yakni distribusi dokter spesialis radiologi tidak merata, dimana 83\% berada di Indonesia bagian barat, tengah 15\% dan timur hanya 2\% (10). Masalah ini perlu adanya sebuah solusi untuk mengatasi tidak meratanya penyebaran tenaga medis yakni salah satunya penerapan Telemedicine. Telemedicine memiliki peran dalam mengatasi tidak meratanya distribusi dokter karena dengan Telemedicine memungkinkan tenaga medis yang spesialis memberikan layanan dari jarak jauh tanpa batas ruang sehingga pasien dapat layanan yang berkualitas (10).

American Telemedicine Association (ATA) dalam buku Telemedicine Toolkit (2017) mendefinisikan Telemedicine sebagai penggunaan informasi medis yang dipertukarkan dari satu situs ke situs lain melalui komunikasi elektronik untuk meningkatkan status kesehatan klinis pasien. Telemedicine memfasilitasi peningkatan cepat pada kesehatan individu dengan menyediakan komunikasi interaktif dua arah antara pasien dan penyedia layanan kesehatan (7). Telemedicine bisa menjadi salah satu opsi sebagai solusi untuk mengatasi keterbatasan tenaga kesehatan (dokter, dokter spesialis-subspesialis) tersebut utamanya dalam memperkuat pelayanan kesehatan dasar dan rujukan di fasilitas pelayanan kesehatan. Sebagai negara kepulauan, pemerataan dan keterjangkauan pelayanan kesehatan masih menjadi kendala. Fasilitas kesehatan belum sepenuhnya dapat dijangkau oleh masyarakat, terutama masyarakat di daerah terpencil, tertinggal, dan terluar (10).

Menurut WHO (2010) layanan Telemedicine paling berkembang secara global adalah teleradiologi dengan lebih dari 60\% negara yang memiliki beberapa bentuk layanan dan lebih dari 30\% negara memiliki layanan yang sudah baik. Sementara proporsi negara dengan bentuk layanan apapun berkisar dari hampir $40 \%$ untuk teledermatologi dan telepatologi. Telepsychiatry hingga sekitar 25\%. Proporsi negara dengan layanan yang mapan di ketiga area tersebut sebanding sekitar 15\% (11). Dalam penerapan Telemedicine sendiri membutuhkan beberapa pertimbangan yang matang karena banyak hambatan yang mengaruhi kesuksesan dalam penerapan Telemedicine antara lain biaya yang tinggi, infrastruktur, keahlian teknis dan hukum meliputi privasi, kerahasiaan pasien, persaingan prioritas sistem kesehatan, dan persepsi kurangnya permintaan layanan Telemedicine (11). Berdasarkan manfaat meningkatkan akses perawatan, ketepatan waktu, meningkatkan kepuasan pasien, meningkatkan keterlibatan pasien, meningkatkan permintaan perawatan dan hemat biaya (7).

\section{Metode Penelitian}

Jenis penelitian ini systematic literature review yang dilakukan untuk mengumpulkan serta mengevaluasi penelitian yang terkait manfaat penerapan Telemedicine. Langkah dalam penelitian systematic literature review terdiri dari beberapa langkah; mendefinisikan tujuan, pencarian literatur, penilaian study, mengkombinasikan hasil dan menetapkan hasil. Kata kunci dan boolean operator yang digunakan untuk pencarian literatur; "Benefit Telemedicine" OR "Utilization Telemedicine" AND "Cost-Effectiveness Telemedicine" OR "Implementation Telemedicine" AND "Archipelago State". Sumber literatur yang digunakan dalam penelitian bersumber dari database online yakni ProQuest, PubMed, Elsevier, Google Scholar, dan Science Direct.

Kriteria eligibilitas dalam penelitian ini terdiri dari kriteria inklusi dan eksklusi. Kriteria inklusi meliputi 1) Artikel ilmiah berbahasa Inggris dan Indonesia, 2) Literatur dalam bentuk artikel ilmiah dan/atau prosiding, 3) Sumber artikel ilmiah dan/atau prosiding dari jurnal minimal terakreditasi sinta 4, 4) Artikel ilmiah dan/atau prosiding bisa diakses, 5) Tahun publikasi artikel ilmiah dan/atau prosiding dari 2010-2020, 6) Jurnal dan/atau prosiding menggunakan data primer, 6) Pembahasan artikel ilmiah meliputi manfaat penerapan Telemedicine, dan 7) Konteks artikel ilmiah di negara kepulauan. Adapun 
kriteria eksklusi yakni 1) Artikel ilmiah yang berbentuk abstrak, 2) Artikel ilmiah yang studi kasusnya bukan negara kepulauan, 3) Artikel bersumber dari blogspot dan 4) Artikel desain cross-sectional. Seleksi literatur menggunakan metode PRISMA (Preferred Reporting Items for Systematic Reviews and Metaanalyses) seperti pada Gambar 1.

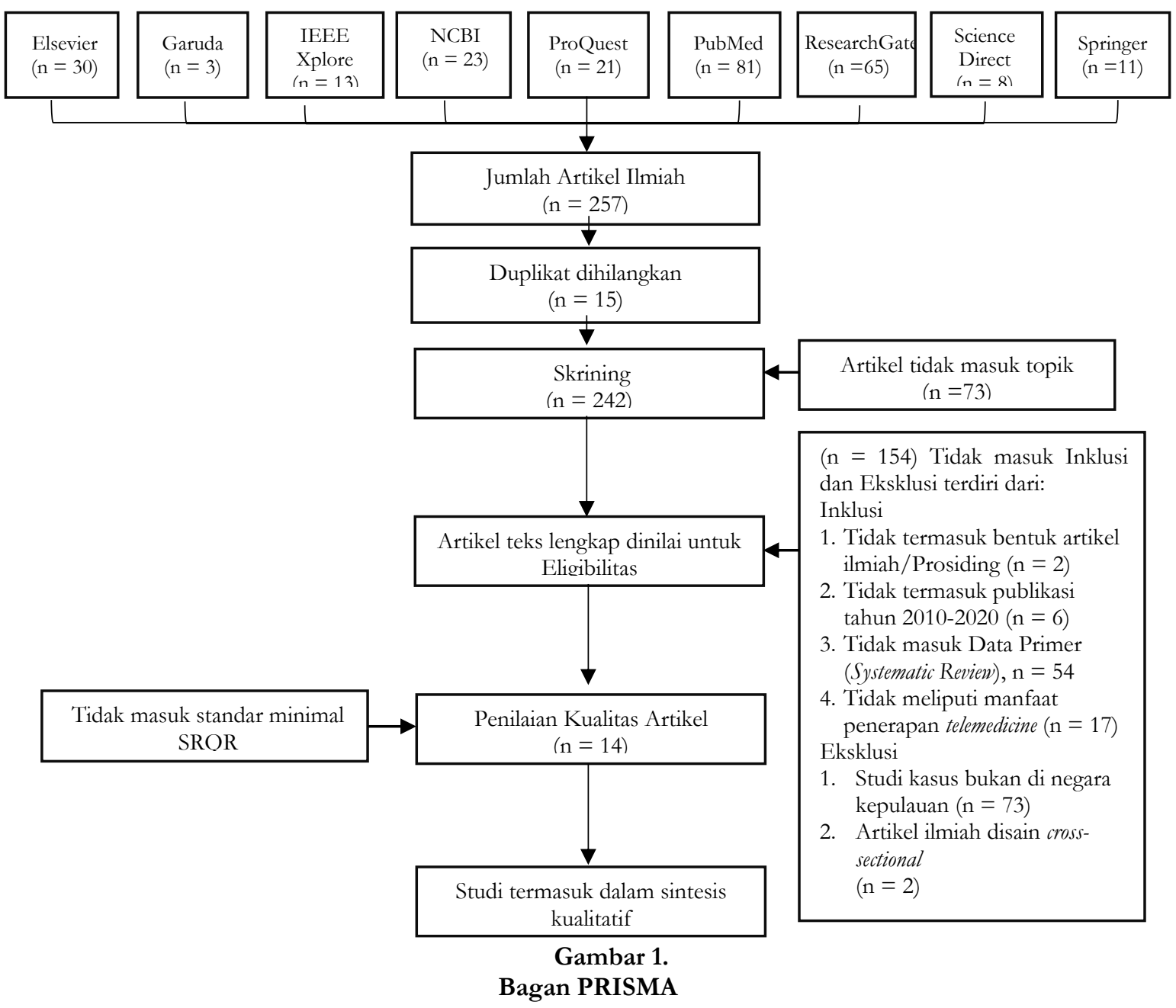

Berdasarkan seleksi literatur dengan menggunakan metode PRISMA yang telah dilakukan, diperoleh 257 artikel ilmiah yang diketahui terdiri dari duplikasi data ada 15. Artikel ilmiah yang dikecualikan tidak masuk topik ada 73, tidak masuk kriteria inklusi \& eksklusi ada 154 dan tidak masuk standar minimal SRQR ada 4. Sehingga hanya ada 10 artikel ilmiah yang digunakan dalam studi literatur. Selain itu agar membatasi ruang lingkup penelitian, peneliti menggunakan metode PICO (Population/Problem, Intervention, Comparison, Outcomes), seperti pada Tabel 1.

Tabel 1.

Ringkasan PICO

\begin{tabular}{ll}
\hline \multicolumn{1}{c}{ Komponen } & \multicolumn{1}{c}{ Keterangan } \\
\hline Population/Problem & Telemedicine \\
Intervention & Evaluasi manfaat penerapan Telemedicine di negara kepulauan \\
Comparison & $\mathrm{n} / \mathrm{a}$ \\
Outcomes & Manfaat Telemedicine (meningkatkan akses perawatan, ketepatan \\
& waktu dalam perawatan, meningkatkan kepuasan \& keterlibatan \\
& pasien, dan meningkatnya permintaan \& hemat biaya) \\
\hline
\end{tabular}

Tahap berikutnya adalah penilaian kualitas artikel yang bertujuan untuk menentukan artikel ilmiah yang memenuhi standar minimal komponen yang sudah ditetapkan. Dalam penelitian ini, peneliti 
menggunakan instrumen Standards for Reporting Qualitative Research (SRQR) yang memiliki 21 komponen penilaian kualitas. Dari 21 komponen, peneliti menetapkan artikel ilmiah harus memenuhi standar minimal 14 komponen guna dapat dijadikan sebagai sumber literatur dalam penelitian ini. Selanjutnya artikel ilmiah yang digunakan dalam penelitian kualitas artikel ilmiah ada 14 literatur, dari14 artikel ilmiah ini diperoleh informasi ada 10 artikel ilmiah yang memenuhi standar minimal. Sedangkan untuk 4 artikel ilmiah yang lainnya tidak memenuhi standar. Sehingga dalam penelitian ini hanya 10 artikel ilmiah yang digunakan menjadi sumber literatur.

Proses data sintesis dalam penelitian ini dilakukan dengan cara membandingkan literatur yang telah memenuhi penilaian kualitas serta kriteria inklusi dan eksklusi. Artikel ilmiah yang tidak memenuhi kriteria dikeluarkan dari sumber literatur. Data sintesis mengacu pada tujuan penelitian yakni mendeskripsikan manfaat dalam penerapan Telemedicine di negara kepulauan. Tahap akhir adalah data ekstraksi. Hasil data berbentuk tabel meliputi nama peneliti, tahun publikasi, judul penelitian, objek penelitian, disain penelitian, tempat penelitian, dan manfaat penerapan Telemedicine.

\section{Hasil dan Pembahasan}

Berdasarkan dari hasil penilaian kualitas artikel ilmiah dan data ekstraksi yang sudah dilakukan, diperoleh hanya 10 artikel ilmiah yang akan menjadi literatur dalam penelitian ini. Adapun penerapan Telemedicine di dalam 10 literatur berasal dari negara yang berbeda seperti Tabel 2.

Tabel 2.

Penelitian berdasarkan Negara Kepulauan

\begin{tabular}{|c|c|c|c|c|}
\hline No. & Judul Penelitian & Negara & Populasi/Kasus & $\begin{array}{c}\text { Jenis } \\
\text { Layanan }\end{array}$ \\
\hline 1. & $\begin{array}{l}\text { Clinicians perceptions of a Telemedicine system: } \\
\text { a mixed method study of Makassar City, } \\
\text { Indonesia }\end{array}$ & Indonesia & $\begin{array}{l}100 \text { Dokter di } 39 \\
\text { Klinik terkait } \\
\text { Telemedicine }\end{array}$ & Telemedicine \\
\hline 2. & $\begin{array}{l}\text { Implementation of Telemedicine in Cape Verde: } \\
\text { Influencing Factors }\end{array}$ & Cape Verde & $\begin{array}{l}\text { Dokter, perawat, dan } \\
\text { profesional }\end{array}$ & Telekonsultasi \\
\hline 3. & $\begin{array}{l}\text { Layanan Telemedis di Indonesia: Keniscayaan, } \\
\text { Risiko, dan Batasan Etika }\end{array}$ & Indonesia & 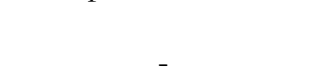 & Telekonsultasi \\
\hline 4. & $\begin{array}{l}\text { Low Utilization of Telemedicine in the First Year } \\
\text { Trial: A Case in the Province of West Papua, } \\
\text { Indonesia }\end{array}$ & Indonesia & $\begin{array}{l}\text { Dinkes provinsi, } \\
\text { Tenaga profesional } \\
\text { dan Tenaga Teknis } \\
\text { terlibat dalam } \\
\text { TEMENIN }\end{array}$ & $\begin{array}{l}\text { Telemedicine } \\
\text { Indonesia } \\
\text { (TEMENIN) }\end{array}$ \\
\hline 5. & $\begin{array}{l}\text { Telemedicine Consultation as an Indicator of } \\
\text { Local Telemedicine Champions' Contributions, } \\
\text { Health Care System Needs or Both: Tales } \\
\text { from Two Continents }\end{array}$ & Cabo Verde & $\begin{array}{c}\text { 2.444 Pasien, kasus } \\
\text { konsultasi }\end{array}$ & Telekonsultasi \\
\hline 6. & $\begin{array}{l}\text { Telemedicine in Resource-Limited Settings to } \\
\text { Optimize Care for Multidrug-Resistant } \\
\text { Tuberculosis }\end{array}$ & $\begin{array}{l}\text { Papua New } \\
\text { Guinea }\end{array}$ & 237 pasien, kasus TBC & Telemedicine \\
\hline 7. & $\begin{array}{l}\text { Telemedicine Service Improves Access to } \\
\text { Pediatric Cardiology in Cape Verde }\end{array}$ & Cape Verde & $\begin{array}{l}31 \text { Pasien, kasus } \\
\text { kelainan jantung }\end{array}$ & Telekardiologi \\
\hline 8. & $\begin{array}{l}\text { Telemedicine Utilization to Support the } \\
\text { Management of the Burns Treatment } \\
\text { Involving Patient Pathways in Both } \\
\text { Developed and Developing Countries: A Case } \\
\text { Study }\end{array}$ & $\begin{array}{l}\text { Sao Tome } \\
\text { \& Principe }\end{array}$ & $\begin{array}{l}10 \text { Pasien di STP, } \\
\text { kasus luka bakar }\end{array}$ & $\begin{array}{l}\text { Telekonsultasi } \\
\text { dan } \\
\text { Telerehabilitasi }\end{array}$ \\
\hline 9 & $\begin{array}{l}\text { Telepathology in the Philippines: A Review } \\
\text { and Future Prospects }\end{array}$ & Filipina & Ahli patologi & Telepatologi \\
\hline 10 & $\begin{array}{l}\text { Cabo Verde Telemedicine Program : Initial } \\
\text { Results of Nationwide Implementation }\end{array}$ & Cabo Verde & - & Telemedicine \\
\hline
\end{tabular}


Berdasarkan Tabel 2 diketahui hanya 10 literatur yang digunakan dalam penelitian. Semua literatur ini berasal dari berbagai negara, mulai dari yang terbanyak negara Cape Verde dengan ada 4 literatur, negara Indonesia memiliki 3 literatur, dan yang paling sedikit berasal dari negara Philippines, Papua New Guinea, dan Sao Tome \& Principe dengan masing-masing memiliki 1 literatur. Penjabaran empat manfaat penerapan Telemedicine dalam artikel ilmiah yang digunakan dijelaskan dalam Tabel 3.

Tabel 3.

Data Ektraksi

\begin{tabular}{|c|c|c|c|c|c|c|c|}
\hline \multirow[b]{2}{*}{ No. } & \multirow[b]{2}{*}{ Judul Penelitian } & \multirow[b]{2}{*}{$\begin{array}{l}\text { Nama } \\
\text { Penulis, } \\
\text { Tahun }\end{array}$} & \multirow[b]{2}{*}{ Negara } & \multicolumn{4}{|c|}{ Manfaat Penerapan Telemedicine } \\
\hline & & & & $\begin{array}{l}\text { Peningkatan } \\
\text { Akses } \\
\text { Perawatan }\end{array}$ & $\begin{array}{c}\text { Ketepatan } \\
\text { Waktu }\end{array}$ & $\begin{array}{l}\text { Peningkatan } \\
\text { Kepuasan \& } \\
\text { Keterlibatan } \\
\text { Pasien }\end{array}$ & $\begin{array}{l}\text { Peningkatan } \\
\text { Permintaan \& } \\
\text { Hemat Biaya }\end{array}$ \\
\hline 1 & $\begin{array}{l}\text { Clinicians } \\
\text { perceptions of } \\
\text { a Telemedicine } \\
\text { system: a mixed } \\
\text { method study } \\
\text { of Makassar } \\
\text { City, Indonesia }\end{array}$ & $\begin{array}{l}\text { Dea Indria; } \\
\text { Mohannad } \\
\text { Alajlani; } \\
\text { Hamish S F } \\
\text { Fraser, } 2020\end{array}$ & $\begin{array}{l}\text { Klinik } \\
\text { Perawatan } \\
\text { Primer, } \\
\text { Indonesia }\end{array}$ & & $\begin{array}{l}\text { 1. Ketepatan } \\
\text { waktu dalam } \\
\text { rujukan } \\
\text { bertambah }\end{array}$ & $\begin{array}{l}\text { 1. Berkurang } \\
\text { Rujukan yang } \\
\text { tidak tepat } \\
\text { 2. Waktu tunggu } \\
\text { hasil diagnosis } \\
\text { lebih cepat }\end{array}$ & 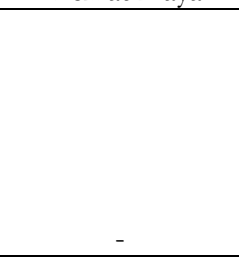 \\
\hline 2 & $\begin{array}{l}\text { Implementation } \\
\text { of Telemedicine } \\
\text { in Cape Verde: } \\
\text { Influencing } \\
\text { Factors }\end{array}$ & $\begin{array}{l}\text { Artur Correira; } \\
\text { Vanda } \\
\text { Azevedo; Luís } \\
\text { Velez Lapao, } \\
2017\end{array}$ & $\begin{array}{l} \\
\text { Lembaga } \\
\text { Jaminan Sosial } \\
\text { Nasional; } \\
\text { Badan } \\
\text { Telekomunikasi } \\
\text { Nasional, Cape } \\
\text { Verde }\end{array}$ & $\begin{array}{l}\text { 1.Hilangnya } \\
\text { hambatan } \\
\text { geografis antara } \\
\text { pasien-dokter } \\
\text { maupun dokter- } \\
\text { dokter spesialis } \\
2 . \text { Mengurangi } \\
\text { prosedur yang } \\
\text { memerlukan } \\
\text { waktu }\end{array}$ & $\begin{array}{l}\text { 1. Mudah } \\
\text { diagnosis dini } \\
\text { 2. Berkurang } \\
\text { rujukan yang } \\
\text { tidak perlu }\end{array}$ & $\begin{array}{l}\text { Pasien mengakses } \\
\text { layanan kesehatan } \\
\text { lebih mudah } \\
\text { dijangkau }\end{array}$ & $\begin{array}{l}\text { Mengurangi resiko } \\
\text { untuk biaya } \\
\text { evakuasi medis/ } \\
\text { perjalanan/pelatih } \\
\text { an }\end{array}$ \\
\hline 3 & $\begin{array}{l}\text { Layanan } \\
\text { Telemedis di } \\
\text { Indonesia: } \\
\text { Keniscayaan, } \\
\text { Risiko, dan } \\
\text { Batasan Etika }\end{array}$ & $\begin{array}{l}\text { Pukovisa } \\
\text { Prawiroharjo; } \\
\text { Peter Pratama; } \\
\text { Nurfanida } \\
\text { Librianty, } 2019\end{array}$ & $\begin{array}{l}\text { Majelis } \\
\text { Kehormatan } \\
\text { Etik } \\
\text { Kedokteran } \\
\text { Pengurus Besar } \\
\text { Ikatan Dokter, } \\
\text { Indonesia }\end{array}$ & & $\begin{array}{l}\text { 1.Dokter mudah } \\
\text { dalam } \\
\text { meningkatkan } \\
\text { layanan medis } \\
\text { yang lebih } \\
\text { berkualitas } \\
\text { 2. Meningkatnya } \\
\text { ketepatan waktu } \\
\text { dan kualitas } \\
\text { layanan dengan } \\
\text { adanya tim ahli }\end{array}$ & & $\begin{array}{l}\text { Mengurangi biaya } \\
\text { transportasi } \\
\text { pasien }\end{array}$ \\
\hline 4 & $\begin{array}{l}\text { Low Utilization } \\
\text { of Telemedicine } \\
\text { in the First } \\
\text { Year Trial: A } \\
\text { Case in the } \\
\text { Province of } \\
\text { West Papua, } \\
\text { Indonesia }\end{array}$ & $\begin{array}{l}\text { Riski } \\
\text { Nugraheni; } \\
\text { Guardian Yoki } \\
\text { Sanjaya; Siti } \\
\text { Setyawati } \\
\text { Mulyono Putri; } \\
\text { Anis } \\
\text { Fuad;mLutfan } \\
\text { Lazuardi; } \\
\text { Ariani Arista } \\
\text { Putri Pertiwi; } \\
\text { Surahyo } \\
\text { Sumarsono; } \\
\text { Mei Neni } \\
\text { Sitaresmi, } 2017 \\
\end{array}$ & $\begin{array}{l}\text { Rumah Sakit } \\
\text { Sorong; Rumah } \\
\text { Sakit Raja } \\
\text { Ampat; } \\
\text { Puskesmas } \\
\text { Oranbari- } \\
\text { Sausapor; } \\
\text { Rumah Sakit } \\
\text { Dr. Wahidin } \\
\text { Sudirohusodo, } \\
\text { Indonesia }\end{array}$ & $\begin{array}{l}\text { 1. Pasien tidak } \\
\text { harus melakukan } \\
\text { perjalanan ke } \\
\text { rumah sakit } \\
2 . \\
\text { Menghilangkan } \\
\text { hambatan } \\
\text { geografis dan } \\
\text { komunikasi }\end{array}$ & $\begin{array}{l}\text { 1. Meningkat } \\
\text { kemudahan } \\
\text { komunikasi } \\
\text { antar penyedia } \\
\text { layanan } \\
\text { kesehatan }\end{array}$ & $\begin{array}{l}\text { 1. Pasien puas } \\
\text { dengan } \\
\text { menggunakan } \\
\text { Telemedicine } \\
\text { 2. Merasa terlibat } \\
\text { selama proses } \\
\text { layanan Telemedicine } \\
\text { berlangsung }\end{array}$ & $\begin{array}{l}\text { Biaya layanan } \\
\text { lebih murah } \\
\text { untuk pasien }\end{array}$ \\
\hline 5 & $\begin{array}{l}\text { Telemedicine } \\
\text { Consultation as } \\
\text { an Indicator of } \\
\text { Local } \\
\text { Telemedicine } \\
\text { Champions' }\end{array}$ & $\begin{array}{l}\text { Rifat Latifi, } \\
\text { MD; Vanda } \\
\text { Azevedo, MD; } \\
\text { Arian Boci, } \\
\text { MPH, MSC; } \\
\text { Afshin Parsikia, }\end{array}$ & $\begin{array}{l}\text { Rumah Sakit } \\
\text { Dr. Agostinho; } \\
\text { Rumah Sakit } \\
\text { Dr. Bapitsa de } \\
\text { Sousa, Cape } \\
\text { Verde }\end{array}$ & $\begin{array}{l}\text { 1. Meningkatkan } \\
\text { akses perawatan } \\
\text { 2. Meningkatkan } \\
\text { cangkupan } \\
\text { layanan spesialis } \\
\text { radiologi ke }\end{array}$ & & $\begin{array}{l}\text { Pasien puas } \\
\text { dengan bisa lebih } \\
\text { mudah dalam } \\
\text { akses layanan } \\
\text { kesehatan melalui } \\
\text { Telemedicine }\end{array}$ & $\begin{array}{l}\text { Telemedicine } \\
\text { menjadi salah } \\
\text { satu opsi yang } \\
\text { diakui } \\
\text { mengeluarkan }\end{array}$ \\
\hline
\end{tabular}


ISSN (Print) : 2354-8932

\begin{tabular}{|c|c|c|c|c|c|c|c|}
\hline \multicolumn{4}{|c|}{ NOH } & \multicolumn{4}{|c|}{ IssIv (Unine) } \\
\hline \multirow{3}{*}{ No. } & \multirow[b]{2}{*}{ Judul Penelitian } & \multirow[b]{2}{*}{$\begin{array}{l}\text { Nama } \\
\text { Penulis, } \\
\text { Tahun }\end{array}$} & \multirow[b]{2}{*}{ Negara } & \multicolumn{4}{|c|}{ Manfaat Penerapan Telemedicine } \\
\hline & & & & $\begin{array}{l}\text { Peningkatan } \\
\text { Akses } \\
\text { Perawatan }\end{array}$ & $\begin{array}{l}\text { Ketepatan } \\
\text { Waktu }\end{array}$ & $\begin{array}{c}\text { Peningkatan } \\
\text { Kepuasan \& } \\
\text { Keterlibatan } \\
\text { Pasien }\end{array}$ & $\begin{array}{c}\text { Peningkatan } \\
\text { Permintaan \& } \\
\text { Hemat Biaya }\end{array}$ \\
\hline & $\begin{array}{l}\text { Contributions, } \\
\text { Health Care } \\
\text { System Needs } \\
\text { or Both: Tales } \\
\text { from Two } \\
\text { Continents }\end{array}$ & $\begin{array}{l}\text { MD, MPH; } \\
\text { Fortesa Latifi, } \\
\text { MSc; Ronald C. } \\
\text { Merrell, MD, } \\
2017\end{array}$ & & $\begin{array}{l}\text { daerah terpencil } \\
\text { yang kurang } \\
\text { terlayani }\end{array}$ & & & $\begin{array}{l}\text { biaya rendah } \\
\text { dalam Skrining }\end{array}$ \\
\hline 6 & $\begin{array}{l}\text { Telemedicine in } \\
\text { Resource- } \\
\text { Limited } \\
\text { Settings to } \\
\text { Optimize Care } \\
\text { for Multidrug- } \\
\text { Resistant } \\
\text { Tuberculosis }\end{array}$ & $\begin{array}{l}\text { G. Khai Lin } \\
\text { Huang; Gibson } \\
\text { Pawape; } \\
\text { Magdalene } \\
\text { Taune; Stenard } \\
\text { Hiasihri; Pilar } \\
\text { Ustero; Daniel } \\
\text { P. O’Brien; } \\
\text { Philipp du } \\
\text { Cros; Steve } \\
\text { Graham; } \\
\text { Richard } \\
\text { Wootton; } \\
\text { Suman S. } \\
\text { Majumdar, } \\
\text { 2019 }\end{array}$ & $\begin{array}{l}\text { Rumah Sakit } \\
\text { Umum Daru, } \\
\text { Papua New } \\
\text { Guinea }\end{array}$ & - & $\begin{array}{l}\text { 1. Memudahkan } \\
\text { ketepatan waktu } \\
\text { dalam } \\
\text { pengambilan } \\
\text { keputusan oleh } \\
\text { konsolium TB } \\
\text { 2. Menurunkan } \\
\text { jumlah pasien } \\
\text { mangkir yang } \\
\text { gagal } \\
\text { pengobatan } \\
\text { 3. } \\
\text { Mengoptimalka } \\
\text { n para ahli } \\
\text { merawat pasien }\end{array}$ & $\begin{array}{l}\text { 1. Pasien } \\
\text { sebagaian besar } \\
\text { menyatakan } \\
\text { lebih puas } \\
\text { Telemedicine } \\
\text { bermanfaat }\end{array}$ & $\begin{array}{l}\text { Telemedicine } \\
\text { menggunakan } \\
\text { biaya yang } \\
\text { rendah }\end{array}$ \\
\hline 7 & $\begin{array}{l}\text { Telemedicine } \\
\text { Service } \\
\text { Improves } \\
\text { Access to } \\
\text { Pediatric } \\
\text { Cardiology in } \\
\text { Cape Verde }\end{array}$ & $\begin{array}{l}\text { Luís Velez } \\
\text { Lapao; Miguel } \\
\text { Lopes, } 2013\end{array}$ & $\begin{array}{l} \\
\text { Rumah Sakit } \\
\text { Dr. Agostinho } \\
\text { Neto, Cape } \\
\text { Verde }\end{array}$ & $\begin{array}{l}\text { Akses layanan } \\
\text { kesehatan bisa } \\
\text { dari perangkat } \\
\text { pasien/satelit } \\
\text { Telemedicine }\end{array}$ & $\begin{array}{l}\text { 1. Pemberian } \\
\text { pengobatan } \\
\text { pasien lebih } \\
\text { cepat } \\
\text { 2. Ketepatan } \\
\text { waktu dalam } \\
\text { pengambilan } \\
\text { keputusan antar } \\
\text { spesialis lebih } \\
\text { cepat }\end{array}$ & $\begin{array}{l}\text { 1. Pasien } \\
\text { mendapatkan } \\
\text { layanan } \\
\text { kesehatan lebih } \\
\text { cepat } \\
\text { 2. Pasien terlibat } \\
\text { selama proses } \\
\text { layanan } \\
\text { Telemedicine } \\
\text { berlangsung }\end{array}$ & $\begin{array}{l}\text { 1. Adanya } \\
\text { penghematan } \\
\text { biaya penyedia } \\
2 . \\
\text { Menghilangkan } \\
\text { biaya perjalanan } \\
\text { ke RS } \\
\text { 3. Mengurangi } \\
\text { resiko finansial } \\
\text { evakuasi medis } \\
\text { pada pasien }\end{array}$ \\
\hline 8 & $\begin{array}{l}\text { Telemedicine } \\
\text { Utilization to } \\
\text { Support the } \\
\text { Management of } \\
\text { the Burns } \\
\text { Treatment } \\
\text { Involving } \\
\text { Patient } \\
\text { Pathways in } \\
\text { Both } \\
\text { Developed and } \\
\text { Developing } \\
\text { Countries: A } \\
\text { Case Study }\end{array}$ & $\begin{array}{l}\text { Shabbir Syed- } \\
\text { Abdul, MSc, } \\
\text { MD; Jeremiah } \\
\text { Scholl, PhD; } \\
\text { Chiehfeng Cliff } \\
\text { Chen, PhD; } \\
\text { Martinho } \\
\text { D.P.S. Santos, } \\
\text { M; Wen-Shan } \\
\text { Jian, PD;Der- } \\
\text { Ming Liou, Ph; } \\
\text { Yu-Chuan Li, } \\
\text { MD, PhD, } \\
\text { 2012 }\end{array}$ & $\begin{array}{l}\text { Rumah Sakit } \\
\text { STP, Sao Tome } \\
\text { and Principe }\end{array}$ & $\begin{array}{l}\text { Mudahan dalam } \\
\text { akses layanan } \\
\text { konsul, } \\
\text { rehabilitasi dan } \\
\text { obat dari jarak } \\
\text { jauh } \\
\text { e }\end{array}$ & $\begin{array}{l}\text { Ketepatan } \\
\text { dalam } \\
\text { menentukan } \\
\text { tingkatan } \\
\text { keparahan lebih } \\
\text { cepat }\end{array}$ & $\begin{array}{l}\text { 1. Memudahkan } \\
\text { komunikasi } \\
\text { pasien-dokter } \\
\text { 2. Pertukaran } \\
\text { Data antara } \\
\text { STP-TMU } \\
\text { menggunakan } \\
\text { enkripsi } \\
\text { 3. Pasien puas } \\
\text { dengan VC } \\
\text { untuk konsultasi } \\
\text { lanjutan }\end{array}$ & $\begin{array}{l}\text { Menghindari } \\
\text { biaya evakuasi } \\
\text { medis yang tidak } \\
\text { diperlukan }\end{array}$ \\
\hline 9 & $\begin{array}{l}\text { Telepathology } \\
\text { in the } \\
\text { Philippines: A } \\
\text { Review and } \\
\text { Future } \\
\text { Prospects }\end{array}$ & $\begin{array}{l}\text { Elizabeth } \\
\text { Arcellana- } \\
\text { Nuqui; Paul A. } \\
\text { Fontelo; Alvin } \\
\text { B. Marcelo, } \\
2017\end{array}$ & $\begin{array}{l}\text { Rumah Sakit } \\
\text { Umum Filipina, } \\
\text { Filipina }\end{array}$ & $\begin{array}{l}\text { 1. Cangkupan } \\
\text { wilayah layanan } \\
\text { meningkat } \\
\text {,2. Layanan } \\
\text { patologi bisa } \\
\text { dilakukan dari } \\
\text { jarak jauh } \\
\end{array}$ & $\begin{array}{l}\text { 1. Mengurangi } \\
\text { waktu tunggu } \\
\text { hasil diagnosis } \\
\text { 2. Mengurangi } \\
\text { waktu } \\
\text { penyelesaian } \\
\text { sitologi } \\
\end{array}$ & & \\
\hline
\end{tabular}




\begin{tabular}{|c|c|c|c|c|c|c|c|}
\hline \multirow[b]{2}{*}{ No. } & \multirow[b]{2}{*}{ Judul Penelitian } & \multirow[b]{2}{*}{$\begin{array}{l}\text { Nama } \\
\text { Penulis, } \\
\text { Tahun }\end{array}$} & \multirow[b]{2}{*}{ Negara } & \multicolumn{4}{|c|}{ Manfaat Penerapan Telemedicine } \\
\hline & & & & $\begin{array}{l}\text { Peningkatan } \\
\text { Akses } \\
\text { Perawatan }\end{array}$ & $\begin{array}{c}\text { Ketepatan } \\
\text { Waktu }\end{array}$ & $\begin{array}{l}\text { Peningkatan } \\
\text { Kepuasan \& } \\
\text { Keterlibatan } \\
\text { Pasien }\end{array}$ & $\begin{array}{c}\text { Peningkatan } \\
\text { Permintaan \& } \\
\text { Hemat Biaya }\end{array}$ \\
\hline 10 & $\begin{array}{l}\text { Cabo Verde } \\
\text { Telemedicine } \\
\text { Program: Initial } \\
\text { Results of } \\
\text { Nationwide } \\
\text { Implementation }\end{array}$ & $\begin{array}{l}\text { Rifat Latifi, } \\
\text { Erion Dasho, } \\
\text { Ronald C } \\
\text { Merrell, Miguel } \\
\text { Lopes, Vanda } \\
\text { Azevedo, } \\
\text { Flamur } \\
\text { Bekteshi, } \\
\text { Kalterina L } \\
\text { Osmani, } \\
\text { Kucani Julian, } \\
\text { et al, 2014 }\end{array}$ & 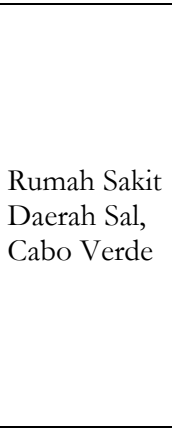 & $\begin{array}{l}\text { Layanan } \\
\text { konsultasi } \\
\text { untuk } \\
\text { dermatologi } \\
\text { dan ahli bedah } \\
\text { trauma bisa dari } \\
\text { jarak jauh }\end{array}$ & $\begin{array}{l}\text { Layanan } \\
\text { Konsultasi } \\
\text { secara realtime }\end{array}$ & $\begin{array}{l}\text { Selama terlibat } \\
\text { menggunakan } \\
\text { Telemedicine pasien } \\
\text { merasa puas } \\
\text { terutama dengan } \\
\text { adanya } \\
\text { teledermatologi, } \\
\text { telekardiologi dan } \\
\text { teletrauma }\end{array}$ & $\begin{array}{l}\text { 1. Meningkatnya } \\
\text { permintaan } \\
\text { layanan konsultasi } \\
\text { jarak jauh } \\
\text { 2. Mengurangi } \\
\text { pengeluaran biaya } \\
\text { perjalanan ke RS }\end{array}$ \\
\hline
\end{tabular}

Hasil dari ekstraksi data diperoleh dari 10 literatur didapatkan informasi hanya $5(50 \%)$ literatur yang membahas semua manfaat penerapan Telemedicine (2)(6)(21)(22)(23). Sedangkan 5 (50\%) literatur lainnya hanya membahas sebagian manfaat saja (1)(4)(9)(10)(24). Hasil analisis dari keempat manfaat penerapan Telemedicine, manfaat yang paling banyak dibahas yakni manfaat ketepatan waktu dalam perawatan ada $9(90 \%)$ literatur (1)(2)(4)(6)(9)(10)(21)(22)(23)(24). Manfaat peningkatan kepuasan \& keterlibatan pasien ada $8(80 \%)(2)(3)(6)(9)(10)(21)(22)(23)$. Manfaat peningkatan permintaan dan hemat biaya ada $8(80 \%)$ literatur (1)(2)(3)(6)(9)(21)(22)(23). Paling sedikit pada manfaat peningkatan akses perawatan yakni hanya ada $7(70 \%)$ literatur dari seluruh literatur yang digunakan (2)(3)(4)(6)(21)(22)(23). Berdasarkan hasil persentase ini dapat menunjukkan bahwa manfaat penerapan Telemedicine di negara kepulauan belum merata pada keempat manfaat.

\section{Manfaat Peningkatan Akses Perawatan}

Peningkatan akses perawatan menurut AHIMA antara lain: Telemedicine memberikan pasien akses layanan kesehatan melalui perangkat milik pasien atau pusat satelit Telemedicine terdekat; memberikan alternatif yang lebih nyaman untuk pasien dalam mencari perawatan; memudahkan pasien di daerah pedesaan mendapatkan akses layanan kesehatan di klinik atau rumah sakit yang memiliki spesialis; mengurangi banyak upaya untuk pasien dengan kondisi kronis menemui spesialis mereka; mengurangi lama waktu tunggu mendapatkan layanan; membuat pasien di daerah pedesaan dapat mencari pertolongan medis dengan lebih nyaman dan efisien tanpa mengorbankan kesehatan mereka sendiri; serta menghilangkan perjalanan yang memberatkan pasien (7).

Berdasarkan hasil analisis yang diperoleh dari literatur, hal yang banyak dibahas adalah menghilangkan perjalanan yang memberatkan pasien, selanjutnya memudahkan pasien di daerah pedesaan mendapatkan akses layanan kesehatan di klinik atau rumah sakit yang memiliki spesialis dan paling sedikit akses layanan kesehatan melalui perangkat pasien/pusat satelit Telemedicine terdekat. Penjelasan lebih rinci adalah sebagai berikut: 1) Menghilangkan perjalanan yang memberatkan pasien, contohnya antara lain: pasien yang berasal dari negara Sao Tome \& Principe bisa mendapatkan layanan konsultasi/rehabilitasi/obat dari spesialis di Rumah Sakit Taipei (6); layanan patologi di Filipina bisa dilakukan dari jarak jauh (4); serta pasien di negara Cabo Verde bisa mendapatkan layanan konsultasi dermatologi/ahli bedah trauma dari spesialis yang ada di negara Portugal (21). 2) Memudahkan pasien di daerah pedesaan mendapatkan akses layanan kesehatan di klinik atau rumah sakit yang memiliki spesialis, contohnya antara lain: menghilangkan hambatan geografis antara pasien dengan dokter lokal di Cape Verde maupun dokter dari Cape Verde -dokter spesialis di Portugal dimana mereka saling terhubung dari jarak jauh melalui Telemedicine (2); serta menghilangkan hambatan geografis pasien dengan dokter lokal di Indonesia dan komunikasi lebih mudah melalui Telemedicine (23). 3) Akses layanan kesehatan melalui perangkat pasien/pusat satelit Telemedicine terdekat, contohnya antara lain: memudahkan pasien dengan menyediakan akses layanan kesehatan dari perangkat pasien atau melalui satelit Telemedicine terdekat. 
Berdasarkan pembahasan diatas, diperoleh hanya dua negara yang terlihat mendapatkan banyak manfaat dari Telemedicine yakni negara Cape Verde selama program terus berjalan bekerjasama dengan negara Portugal yang memiliki banyak spesialis, lalu ada negara Sao Tome \& Principe dalam kasus luka bakar bekerja sama dengan Taipei untuk membantu menangani masalah kesehatan. Selanjutnya, dari peneliti tidak menemukan aplikasi apa yang digunakan dan bagaimana teknisnya dalam menjalankan Telemedicine pada kedua negara tersebut.

\section{Manfaat Ketepatan Waktu dalam Perawatan}

Ketepatan waktu perawatan dalam perawatan menurut AHIMA antara lain: mengurangi lama waktu pasien untuk bepergian; atau memudahkan pasien dalam sarana untuk pergi ke rumah sakit dalam situasi darurat; memungkinkan perawatan kesehatan yang sesuai dibutuhkan oleh pasien; melalui Telemedicine dalam keadaan darurat penyedia dapat memberikan nasihat medis untuk pengobatan sendiri; memesan resep untuk segera digunakan; mengirimkan instruksi untuk menemui spesialis; memudahkan penegakan diagnosis pasien; dirawat (atau obat yang diresepkan) dengan cara yang efisien dan tepat waktu; serta penyedia, perawat, atau staf tambahan dapat menggunakan teknologi telekomunikasi untuk berkomunikasi dengan penyedia atau spesialis di luar lokasi (7). Dari hasil analisis yang didapatkan dari literatur, paling banyak dibahas yakni memudahkan penegakan diagnosis pasien dan paling sedikit memungkinkan perawatan kesehatan yang sesuai dibutuhkan oleh pasien.

Memudahkan penegakan diagnosis pasien, contohnya antara lain: memudahkan dalam melakukan diagnosis dini pada pasien di Cape Verde (2), adanya tim ahli di jaringan Telemedicine meningkatkan kualitas layanan dalam ketepatan waktu diagnosis pasien di Indonesia (1); pengambilan keputusan oleh konsolium TB di Papua New Guinea lebih cepat sehingga meningkatkan ketepatan waktu dalam memberikan perawatan yang dibutuhkan pasien (9); pemberian pengobatan pasien di Cape Verde lebih cepat melalui Telemedicine (22); meningkatkan ketepatan waktu dengan pengambilan keputusan antar spesialis yang lebih cepat (22); meningkatkan ketepatan waktu dengan menentukan tingkatan keparahan luka bakar pasien dari Sao Tome \& Principe lebih cepat oleh spesialis di Taipei (6); mengurangi waktu tunggu hasil diagnosis pasien di Filipina (4); serta mengurangi lama waktu penyelesaian sitologi di Filipina (4).

Memungkinkan perawatan kesehatan yang sesuai dibutuhkan oleh pasien, contohnya antara lain: meningkatkan ketepatan waktu dalam rujukan dimana pasien bisa saja dalam kondisi yang darurat (10); serta mengurangi rujukan yang tidak perlu dimana pasien yang tinggal di Cape Verde kondisinya masih bisa ditangani oleh dokter lokal dengan adanya bantuan dari spesialis yang ada di Portugal (2). Berdasarkan pembahasan diatas, didapatkan negara yang paling banyak mendapatkan manfaat yakni Cape Verde ini sudah menjadi hal lumrah karena program Telemedicine sudah berjalan mulai dari tahun 2000 di pulau Brava (2). Selain itu, ada juga dua negara yang memperoleh manfaat Telemedicine yakni Papua New Guinea dalam menghadapi wabah MDR-TB di Pulau Daru (9) dan Sao Tome \& Principe dalam penanganan kasus luka bakar yang sering terjadi. Sedangkan untuk perawatan kesehatan yang sesuai dibutuhkan oleh pasien, Telemedicine menjadi acuan penilaian kondisi pasien perlu dilakukan rujukan atau tidak ke rumah sakit Portugal.

\section{Manfaat Meningkatkan Kepuasan dan Keterlibatan Pasien}

Peningkatan kepuasan dan keterlibatan pasien menurut AHIMA antara lain: keterlibatan pasien; adanya kepuasan pasien; meningkatnya kualitas perawatan pasien; serta pengurangan biaya layanan kesehatan (7). Selanjutnya hasil analisis yang telah didapatkan dari literatur, paling banyak dibahas yakni adanya kepuasan pasien dan paling sedikit keterlibatan pasien. Adanya kepuasan pasien, contohnya antara lain: pasien puas dengan berkurangnya lama waktu tunggul hasil diagnosis (10); pasien bisa mengakses layanan kesehatan dari jarak jauh tanpa melakukan perjalanan yang memberatkan (10); akses layanan kesehatan melalui Telemedicine lebih mudah bagi pasien di Cape Verde (3); adanya kepuasan pasien menggunakan Telemedicine karena layanan kesehatan lebih cepat bagi pasien di Cape Verde (22); komunikasi pasien-dokter lebih mudah; Pertukaran data antara STP-TMU menggunakan enkripsi; pasien puas dengan VC untuk konsultasi lanjutan(6); Selama terlibat menggunakan Telemedicine pasien merasa puas terutama dengan adanya teledermatologi, telekardiologi dan teletrauma (21). Keterlibatan pasien, 
contohnya antara lain: merasa terlibat selama proses layanan Telemedicine berlangsung (23); pasien terlibat selama proses layanan Telemedicine berlangsung (22); Selama terlibat menggunakan Telemedicine pasien merasa puas terutama dengan adanya teledermatologi, telekardiologi dan teletrauma (21).

Berdasarkan pembahasan diatas, adanya kepuasan pasien banyak ditemukan pada negara Cape Verde. Penyebabnya, beberapa peneliti yang membahas tentang Telemedicine berfokus pada Cape Verde sebagai studi kasus dalam penelitian mereka. Itu hal lumrah karena penerapan Telemedicine di Cape Verde sudah dimulaisejak lama pada tahun 2013 Telemedicine sudah memiliki 9 jenis layanan spesialis yang sudah berjalan (2). Selain itu, adapun adanya kepuasan pasien terlihat juga di negara Sao Tome \& Principe. Walaupun tidak banyak penelitian yang membahas penerapan Telemedicine di negara tersebut.Namun, informasi yang diperoleh peniliti sudah cukup untuk menjelaskan pada bagian mana menunjukan kepuasan pasien dalam menggunakan Telemedicine.Selanjutnya pada keterlibatan pasien terlihat perannya sebagai pengguna yang kekonsitenan menggunakan Telemedicine pasien, ini terlihat adanya banyaknya permintaan layanan konsultasi jarak jauh.Perkembangan Telemedicine di Cape Verde tidak terlepas dari keterlibatan pasien.

\section{Manfaat Meningkatnya Permintaan dan Hemat Biaya}

Meningkatnya permintaan dan hemat biaya menurut AHIMA antara lain: layanan yang mudah; efisien; nyaman; serta meningkatnya ekspektasi pasien (7). Selanjutnya, berdasarkan hasil analisis yang telah diperoleh paling banyak dibahas yakni layanan yang efisien dan paling sedikit meningkatnya ekspektasi pasien. Layanan yang efisien, contohnya antara lain: mengurangi resiko untuk mengeluarkan biaya evakuasi medis/perjalanan pasien di Cape Verde ke Portugal (2); mengurangi biaya transportasi pasien yang tinggal di Indonesia (1); biaya layanan lebih murah untuk pasien yang tinggal di Indonesia (23); Telemedicine menjadi salah satu pilihan yang diakui mengeluarkan biaya rendah dalam skrining pasien di Cabo Verde (3); Telemedicine menggunakan biaya yang rendah pasien Papua New Guinea (9); adanya penghematan biaya penyedia di Cape Verde (22); menghilangkan biaya perjalanan pasien ke rumah sakit di Cape Verde (22); mengurangi resiko finansial evakuasi medis pada pasien di Cape Verde (22); menghindari biaya evakuasi medis ke Taipei yang tidak diperlukan untuk pasien yang tinggal di Sao Tome \& Principe (6); serta mengurangi pengeluaran biaya perjalanan ke rumah sakit di Cabo Verde (21). Meningkatnya ekspektasi pasien, contohnya yakni meningkatnya permintaan pasien untuk layanan konsultasi jarak jauh di Cabo Verde (21).

Berdasarkan pembahasan diatas, layanan yang efisien banyak diperoleh negara Cape Verde. Layanan efisien ini lebih berfokus pada biaya yang akan dikeluarkan oleh pasien yang mulai dari diagnosis sampai dengan evakuasi medis jika diperlukan. Informasi yang didapatkan dari beberapa penelitian sudah cukup menjelaskan pada bagian mana terjadi efisiensi. Selain itu, adapun dari negara Sao Tome \& Principe untuk efesiensi yang dilakukan tidak jauh berbeda terutama pada evakuasi medis (2). Sedangkan pada bagian meningkatnya ekspektasi pasien sangat minim dibahas dalam 10 literatur. Hanya ada 1 literatur yang membahas yakni penelitian yang dilakukan Ratif Latifi (2014) menyebutkan terjadi peningkatan permintaan pasien di Cabo Verde untuk layanan konsultasi yang dilakukan dari jarak jauh. Namun, perlu kita ketahui juga dibalik banyak manfaat yang telah disebutkan sebelumnya ada hambatanhambatan dalam penerapan Telemedicine di sebuah negara terkhususnya negara kepulauan. Selain banyak manfaat-manfaat yang dijelaskan dalam pembahasan, ada hambatan-hambatan yang perlu diketahui dalam penerapan Telemedicine. Menurut World Health Organization (2010), menyebutkan hambatan yang paling sering dihadapi dalam penerapan Telemedicine antara lain: persepsi biaya Telemedicine terlalu tinggi; infrastruktur terbelakang; minimnya keahlian teknis; kerangka kerja hukum meliputi privasi dan kerahasiaan pasien; sistem kesehatan; serta persepsi minimnya permintaan Telemedicine. (12).

Adapun dari Anderson Rhonda et al (2017) dalam buku Telemedicine Toolkit menyebutkan ada beberapa tantangan yang perlu diperhatikan dalam penerapan Telemedicine sebagai berikut (7): 1) Biaya dan investasi awal biaya dan investasi awal mengacu pada biaya pengembangan dan implementasi program Telemedicine yang dapat dikeluarkan. Sumber daya ini digunakan untuk perencanaan, koordinasi dan konsultasi dengan vendor potensial, implementasi teknologi, memenuhi semua persyaratan, pelatihan, go-live, dukungan awal setelah go-live, dan waktu semua staf Telemedicine. 2) Kurangnya interaksi wajah ke wajah. Lingkungan virtual program Telemedicine dapat dianggap impersonal, penyedia harus memastikan bahwa semua pertemuan Telemedicine bersifat interaktif, dipersonalisasi, dan memberdayakan. Pertemuan pasien yang dipersonalisasi akan mengarah pada kepuasan pasien yang lebih 
tinggi dan skor keterlibatan pasien. 3) Teknologi pasien, teknologi pasien ini mengacu pada teknologi (komputer pasien, tablet, atau smartphone) yang digunakan untuk terhubung dengan penyedia setiap kali menggunakan layanan Telemedicine. Ini terdengar mudah, namun nyatanya ada masalah pada teknologi pasien bisa berupa umpan video yang lambat, video berkualitas rendah, pemadaman internet, dan tidak memiliki fitur keamanan yang sama dengan sistem organisasi. Serta, pada beberapa pasien mungkin ada yang tidak begitu familiar dengan menggunakan perangkat seluler, koneksi internet, atau aplikasi Telemedicine mereka. 4) Pembayaran dan Cakupan Asuransi, pembayaran dan Cangkupan Asuransi mengacu pada aturan dan regulasi mengenai cara pembayaran layanan Telemedicine. Beberapa perusahaan lebih bersedia untuk memasukkan layanan Telemedicine dalam rencana tunjangan mereka.

\section{Kesimpulan}

Negara yang terlibat dalam penelitian yakni Cape Verde, Filipina, Indonesia, Papua New Guinea, dan Sao Tome \& Principe. Negara yang paling banyak mendapatkan manfaat adalah negara Cape Verde dan paling sedikit di Papua New Guinea. Manfaat dari peningkatan akses perawatan yang diperoleh berupa pasien di daerah pedesaan mudah mendapatkan akses layanan kesehatan di klinik atau rumah sakit yang memiliki spesialis, akses layanan kesehatan melalui perangkat pasien/perangkat satelit Telemedicine terdekat. Telemedicine mempunyai manfaat yang besar untuk negara kepulauan sehingga perlu memaksilmalkan penerapannya dengan memperhatikan segi biaya dan investasi awal yang dikeluarkan untuk pengembangan dan implementasi program. Memprioritaskan pembangunan infrastruktur dan meningkatkan jumlah keahlian teknis sesuai kebutuhan untuk mendukung kinerja Telemedicine. Pembuatan lingkungan virtual bersifat interaktif, dipersonalisasi, dan memberdayakan. Penentuan kriteria teknologi perangkat tablet atau smartphone pasien untuk bisa terhubung dengan layanan Telemedicine. Pembuatan regulasi terkait sistem kesehatan menggunakan Telemedicine yang isinya memuat privasi, kerahasiaan pasien, cara pembayaran serta cangkupan asuransi yang ditanggung dalam layanan Telemedicine.

\section{Daftar Pustaka}

1. Prawiroharjo P, Peter P, Librianty N. Layanan Telemedis di Indonesia : Keniscayaan, Risiko, dan Batasan Etika. J Etika Kedokt Indones. 2019;3(1):1-9.

2. Correia A, Azevedo V, Lapão LV. Implementation of Telemedicine in Cape Verde: Influencing Factors. 2017;30(4):255-62.

3. Parsikia A, Latifi F. Telemedicine Consultation as an Indicator of Local Telemedicine Champions' Contributions, Health Care System Needs or Both: Tales from Two Continents. 2019;00(00):1-7.

4. Arcellana-nuqui E, Fontelo PA, Marcelo AB. Telepathology in the Philippines: A Review and Future Prospects. 2016;50(4):201-5.

5. Sarfati D, Dyer R, Vivili P, Herman J, Spence D, Sullivan R, et al. Cancer control in small island nations: from local challenges to global action. Lancet Oncol [Internet]. Elsevier Ltd; 2019;380(9856):1-14. Available from: http://dx.doi.org/10.1016/S1470-2045(19)30511-X

6. Syed-abdul S, Scholl J. Telemedicine Utilization to Support the Management of the Burns Treatment Involving Patient Pathways in Both Developed and Developing Countries: A Case Study. 2012;207-12.

7. Anderson R, Beckett B, Fahy K, Gordon E, Gray A, Kropp S, et al. Telemedicine Toolkit. Chicago: AHIMA; 2017. 1-34 p.

8. Undang-Undang Republik Indonesia Nomor 32 Tabun 2014 Tentang Kelautan. 2014.

9. Huang GKL, Pawape G, Taune M, Hiasihri S. Telemedicine in Resource-Limited Settings to Optimize Care for Multidrug-Resistant Tuberculosis. 2019;7(August):1-5.

10. Indria D, Alajlani M, Fraser HSF. Clinicians perceptions of a Telemedicine system : a mixed method study of Makassar City, Indonesia. BMC Medical Informatics and Decision Making; 2020;7:1-8.

11. Keputusan Menteri Kesehatan Republik Indonesia Nomor HK.02.02/Menkes/409/2016 tentang Rumah Sakit Uji Coba Program Pelayanan Telemedicine Berbasis Video-Conference dan Teleradiologi. Jakarta; 2016.

12. WHO. Telemedicine Opportunities and Developments in Member States. Vol. 2. 2010.

13. ATA. Telehealth: Defining 21 st Century Care. 2020.

14. Krumm M, Syms MJ. Teleaudiology. In: Telemedicine. 2011. p. 1297-304. 
15. Hannah KJ, Ball MJ. Telenursing. Kumar S, Snooks H, editors. British Library; 2011.

16. Alexander E, Butler CD, Darr A, Jenkins MT, Long R., Shipman C., et al. Statement on Telepharmacy. Vol. 74. 2017.

17. Brennan D, Tindall L, Theodoros D, Brown J, Campbell M, Christiana D, et al. A Blueprint for Telerehabilitation Guidelines. 2010;2(2):31-4.

18. Peraturan Menteri Kesehatan Republik Indonesia Nomor 20 Tahun 2019 tentang Penyelenggaraan Pelayanan Telemedicine Antar Fasilitas Pelayanan Kesehatan. 2019.

19. ATA. Telemedicine Basics. 2020.

20. Agoes ER. Praktik Negara-Negara Atas Konsepsi Negara Kepulauan. 2004;I(April):441-64.

21. Latifi R, Dasho E, Merrell RC, Lopes M, Azevedo V, Bekteshi F, et al. Cabo Verde Telemedicine Program: Initial Results of Nationvide Implementation. 2014;20(11):1027-34.

22. Lisboa UN De, Verde C. Telemedicine Service Improves Access to Pediatric Cardiology in Cape Verde. 2013;18.

23. Nugraheni R, Sanjaya GY, Setyawati S, Putri M, Lazuardi L, Arista A, et al. Low Utilization of Telemedicine in the First Year Trial: A Case in the Province of West Papua, Indonesia. 2020;22(Ishr 2019):568-71.

24. Parikh NR, Chang EM, Kishan AU, Kaprealian TB, Steinberg ML, Raldow AC. Time-Driven ActivityBased Costing Analysis of Telemedicine Services in Radiation Oncology. Radiat Oncol Biol [Internet]. Elsevier Inc.; 2020;108(2):430-4. Available from: https://doi.org/10.1016/j.ijrobp.2020.06.053 